ARTIGOS

\title{
A didática de Comênio: entre o método de ensino e a viva voz do professor $^{1}$
}

\section{Comenius' didactics: between teaching method and teacher's live speech}

(i) Professor Titular da Universidade Ibirapuera - UNIB - São Paulo, SP. demilian@uol.com.br.

Resumo: Neste artigo - o qual aprofunda concepções defendidas em tese de doutorado na Faculdade de Educação da Universidade de São Paulo - analisa-se se na Didática Magna, de Comênio, há lugar para a enunciação do professor. Para Comênio, em princípio, o método de ensino governa tão minuciosamente as ações do professor que este desponta como um mero executor anônimo de um plano didático decidido de antemão por eruditos. Com base na Psicanálise e Educação e em suas concepções de sujeito, enunciação e implicação com o saber, procurou-se colocar à prova se a concepção aqui expressa é de fato absoluta na Didática. Tal expediente permitiu trazer à baila uma importante antinomia comeniana, a qual gira em torno da proeminência do método de ensino e da imprescindibilidade da viva voz do professor. A partir de tal antinomia se concluiu que na Didática há lugar para a enunciação do professor, e o mestre não é reduzido a um executor anônimo do método.

Palavras-chave: Comenius, J. A., psicanálise e educação, escola, ensino, aprendizagem

\footnotetext{
${ }^{1}$ Apoio: Coordenação de Aperfeiçoamento de Pessoal de Nível Superior - CAPES
} 


\section{pro.posições}

$e$-ISSN 1980-6248

http://dx.doi.org/10.1590/1980-6248-2016-0101

Abstract: This article - which deepens the concepts debated in our doctoral dissertation at FEUSP - analyzes if there is place for the teacher's living speech in Comenius' Didactica Magna. According to Comenius, the teaching method governs the actions of teachers so thoroughly that teachers are turned into mere anonymous pawns following a didactic plan elaborated beforehand by scholars. Based on Psychoanalysis and Education, and their notions of subject, and of enunciation and its relationship with knowledge, this paper intended to inquire to what degree the concepts here addressed are indeed absolute in Didactics. This made it possible to bring up an important Comenian antinomy regarding the prominence of the teaching method and the necessity of a teacher's living speech. As a result, it can be concluded that Comenius' Didactica Magna enables the teacher's enunciation without reducing the teacher to the anonymous pawn of a method.

Keywords: Comenius, J. A., psychoanalysis and education, school, teaching, learning

\section{A didática de Comênio: entre o método de ensino e a viva voz do}

\section{professor}

Não é sem razão que, ao falar em Comênio, venha de chofre à mente a imagem do pai da Pedagogia moderna, para quem a metodologia de ensino deve estar acima de qualquer questão em termos educacionais (Cauly, 1999; Gomes, 1966; Narodowski, 2001). Em sua obra mais conhecida e talvez também mais influente, a Didática Magna, livro publicado em 1649, o autor protestante assevera com clareza que a metodologia de ensino deve assumir a condução das ações do professor nas instituições escolares.

Todavia, tal ênfase metodológica não deixa de se deparar com importantes contradições no interior na mesmíssima obra (e ainda que essas contradições, por sua vez, não sejam em geral reconhecidas pelos leitores desse texto tão basilar para o discurso educacional moderno). Ora, no presente artigo $^{2}$ o que pretendemos é trazer à baila essa antinomia da Didática Magna. E, conquanto atinjamos esse objetivo, talvez possamos fazer reconhecer que, a despeito da imagem comeniana já consolidada em torno da aposta excessiva no método de ensino, há na obra em questão, a Didática Magna, um destacável lugar (ou ao menos uma brecha literalmente vital) para o professor, para a "voz" ou a enunciação do mestre, no que toca ao exercício de sua profissão nas instituições de ensino.

\footnotetext{
2 Agradecemos à Capes pelo apoio financeiro concedido ao Doutorado no qual demos início às investigações que ora aprofundamos.
} 


\section{pro.posições}

$e$-ISSN 1980-6248

http://dx.doi.org/10.1590/1980-6248-2016-0101

Pois bem, é precisamente em virtude da importância conferida também ao professor e não apenas ao método de ensinar que o pensamento do protestante Comênio ganha interesse para o campo da Psicanálise e Educação (campo no qual se inscreve o presente artigo). Afinal, os pesquisadores dessa área se alinham aos que colocam em xeque a alegada "superfluidade do professor" diante do emprego de técnicas de ensino que, pautadas pela mais estrita observância de procedimentos metodológicos objetivos, excluem a subjetividade docente, como se ela não representasse mais do que um fator de irracionalidade enquistado no ensino escolar.

Para a Psicanálise e Educação, tal exclusão da singular enunciação do professor implica a desumanização do ensino e, a fortiori, do aprendizado escolar. E, por sua vez, essa desumanização do professor e do aluno provocada pela exclusão do sujeito é a marca por excelência da racionalidade técnico-instrumental, racionalidade cuja pretensão é também a de fazer do ensino e do aprendizado pares narcísicos, isto é, réplicas um do outro. É que, segundo os referidos parâmetros técnico-instrumentais, somente a mais pura concordância entre o que é ensinado pelo professor e o que é aprendido pelo aluno daria, por suposto, prova cabal da eficácia do controle técnico obtido na educação escolar, por força da estrita observância metodológica. Já ao contrário disso, e segundo o campo da Psicanálise e Educação, o que é ensinado e o que é aprendido não são nem devem ser pares narcísicos ou réplicas. Afinal, muito embora seja imprescindível que haja uma relação de consistência entre uma e outra coisa, é desejável também que se estabeleça uma "diferenciação" entre elas, no sentido, por exemplo, de que a apropriação de conhecimentos públicos pelo aluno passe por seus "processos digestivos". Ou seja, é desejável que o aluno se aproprie singularmente dos conhecimentos socialmente validados que lhe são ensinados na escola pelo professor (o que implica, portanto, que o estrito controle técnico sobre aquilo que o aluno aprende é indesejável $\left.{ }^{3}\right)$. E para que isso aconteça, é fundamental, a nosso ver, que o ensino escolar seja autoral, o que então põe em pauta a singularidade subjetiva do mestre ao ensinar. Nesses termos, a relação singular do

\footnotetext{
${ }^{3} \mathrm{E}$ mais ainda: o inconsciente o torna impossível, uma vez que ele sobredetermina o modo como o sujeito lida com os conhecimentos públicos. De mais a mais, o inconsciente (isto é, o saber inconsciente) é "equívoco", razão pela qual a pretensão tecnicista de que seja estabelecida uma relação unívoca entre o ensinado e o aprendido acaba falhando. Ou seja: o inconsciente do professor e o do aluno impossibilitam que o ensinado e o aprendido sejam inequivocamente iguais. Todavia, nem por isso a pretensão tecnicista de univocidade na educação é inócua, posto que, nesse caso, o "retorno do recalcado" (isto é, do inconsciente) pode acabar ocorrendo - seja no caso do professor, seja no caso do aluno - sob a forma de sintoma, psicopatologia, etc., e isso em virtude do teor narcísico ou alienante da educação tecnicista.
} 


\section{pro.posıções}

$e$-ISSN 1980-6248

http://dx.doi.org/10.1590/1980-6248-2016-0101

professor com o saber ${ }^{4}$ nos parece ser o elemento basilar de uma educação escolar não massificada.

É tendo isso em mente que procuraremos, então, nos deter na antinomia comeniana, que gira em torno, por um lado, da proeminência do método de ensino e, por outro, da imprescindibilidade da "pessoa" do professor. Nosso esforço será, pois, o de tentar mostrar que na Didática Magna esses dois aspectos não se excluem mutuamente. A propósito disso, Gasparin (1994) alerta que a reflexão comeniana é marcada por inúmeras antinomias fecundas, fato que nos autoriza ainda mais a explorar uma dentre as tantas antinomias que encontram lugar em sua obra:

As antinomias [de Comênio] manifestam-se tanto no plano da consciência individual conforme atesta o drama íntimo que viveu pelo fato de ser teólogo e ter que se dedicar a questões escolares -, quanto nos princípios, que constituem a tessitura de sua arte, em que se destacam as polarizações entre natural e sobrenatural, divino e humano, religioso e laico ${ }^{5}$, relativo e absoluto, singular e universal, novo e velho, medieval e moderno, graça de Deus e educação humana, continuidade e ruptura, religião e ciência, ensino e aprendizagem, natureza e arte, artesanato e manufatura, instrução e educação, dedução e indução, natureza e mecânica; e muitas outras. (p. 171)

Sendo assim, apreciaremos em um primeiro momento a exaltação comeniana do método de ensino, bem como aquilo que a fundamenta teoricamente. E analisaremos, em um segundo momento, a visada de Comênio segundo a qual o professor que se põe a ensinar conhecimentos em sala de aula não se reduz a uma mera engrenagem do sistema educacional. Por fim, e conquanto tenhamos ao menos em parte conseguido trazer à baila tal antinomia, poderemos então asseverar que nem tudo na Didática Magna se reduz à técnica, e há lugar nessa obra também para algo da ordem do que na Psicanálise e Educação se denomina sujeito.

\footnotetext{
${ }^{4}$ Vale destacar aqui que "saber" concerne ao "saber inconsciente, ao saber latente". Nesse sentido, "saber" difere de "conhecimento", ainda que esses se articulem sutilmente. Afinal, o "conhecimento" é manifesto, consciente (diferentemente do "saber", que é latente, inconsciente).

5 Cambi (1999, p. 277) também destaca que Comênio tanto reafirma a educação religiosa quanto promove, paradoxalmente, o ensino laico no interior de instituições escolares cuja administração deve ser levada a cabo pelos Estados-Nação e em nome dos Estados-Nação.
} 


\section{pro.posıções}

http://dx.doi.org/10.1590/1980-6248-2016-0101

$e$-ISSN 1980-6248

\section{Comênio e a proeminência do método de ensino}

São notórias as pretensões metodológicas da Didática Magna. Cauly (1999), por exemplo, define tal obra como o Discurso do Método da educação. Segundo tal autor, a Didática de Comênio é um dos mais relevantes marcos da apropriação pedagógica da ideia de método. Narodowski (2001), por sua vez, enfatiza que em Comênio a preocupação pedagógica recai centralmente sobre o método de ensino (ao contrário de recair, por exemplo, sobre o corpo da criança, tal como ocorreria hegemonicamente a partir de Rousseau). De mais a mais, o fato mesmo de a obra apresentar o subtítulo "Tratado da arte universal de ensinar tudo a todos" o denota claramente.

Ora, mas ainda que tais pretensões didático-metodológicas sejam incontestes no livro em questão, é preciso aqui recompor, mesmo que de modo sabidamente parcial, algumas das razões comenianas que buscam legitimar essas pretensões.

Segundo nosso autor: "É lícito, foi lícito e sempre será lícito procurar as coisas grandes [magnas]. E nunca será em vão o trabalho começado em nome do Senhor”' (Comênio, 1966, p. 52). Trabalho começado, entremeado e encerrado em nome do Senhor: tal é o caso da Didática Magna. Trabalho vultoso que, entretanto, não denota o menor traço de soberba, na medida em que tudo nele está reportado ao reitor universal, que é Deus. E, desde que o coração do homem não se encha com tal soberba na procura pela magnificência, ele não perderá então a sabedoria, afirma o morávio. Por certo, isso quer dizer que é lícito ao cristão procurar, no que toca ao ensino, por uma didática não apenas grandiosa, isto é, procurar não apenas pela arte de ensinar algumas coisas a alguns (ou até mesmo à maioria), mas sim procurar por uma Didática mais do que grande, a saber, uma Didática universal em seus fins e meios.

A Didática Magna pretende, portanto, estipular o método de ensinar tudo a todos totalmente, método que implica também ensinar os alunos com certeza, rapidez, e solidez totais. Eis que o autor nos propõe, dessa forma, o método de ensinar que - a seus olhos -verdadeiramente faz jus ao título de "magno", na medida em que é estabelecido a priori, ou seja, na medida em que é deduzido a partir da ordem imutável das coisas. Em outras palavras, o método de ensino deve ser deduzido da perene harmonia das leis universais da natureza, harmonia que deriva de Deus (sendo Deus o pai da natureza). Tal método, portanto, não poderia decorrer apenas de observações recolhidas a posteriori e, logo, pautadas meramente no modo prático pelo qual os 


\section{pro.posıções}

$e$-ISSN 1980-6248

http://dx.doi.org/10.1590/1980-6248-2016-0101

alunos aprendem com mais facilidade esta ou aquela disciplina. Para o morávio, um método magno deve servir a toda e qualquer disciplina de estudo, assim como deve fazê-lo em qualquer momento ou contexto. Daí a necessidade de ser deduzido a priori.

Será graças à imitação da ordem natural, portanto, que os alunos poderão vir a ser conduzidos, na escola, a qualquer altura do saber. E se o aluno não chegar a ter êxito ao fazêlo, isso não se deverá a uma inteligência obtusa de sua parte. Ao contrário, tal impossibilidade decorrerá do fato de que "os degraus não estão bem dispostos e que são curtos, gastos e arruinados, ou seja, [de] que o método é confuso" (Comênio, 1966, p. 170). Em outros termos, se um aluno não aprende são as escolas as responsáveis por isso, responsabilidade que se deve tanto ao fato de não estar abertas indistintamente a todos os alunos ("ensinar a todos") quanto de lançar mão de métodos duros, obscuros e confusos (métodos incapazes de "ensinar tudo"').

De acordo com o morávio, o emprego do método natural pelos professores seria muito mais fácil e rápido do que o emprego dos métodos confusos. E tal facilidade e rapidez derivariam de que a conveniente consolidação dos fundamentos daquilo que se ensina não implica, de modo algum, tempo perdido. Ao contrário, a consolidação de fundamentos consolidação que deve ocorrer antes de realizados quaisquer novos avanços na aquisição do conhecimento - implica economia de tempo, trabalho e fadiga posteriores. Em outras palavras, as lições devem - à luz do método - ser ensinadas gradualmente, isto é, segundo a progressão que é própria à ordem da natureza. É importante destacar ainda que, de acordo com Cauly (1999), deve-se à essência gradualista do método o

fato de ele próprio ser transmissível e comunicável universalmente sem que fiquemos a priori desanimados com a complexidade desconcertante de regras que não o são [isto é, de regras que não são verdadeiramente a priori], ou mantidos à distância pelo mistério de uma arte oculta. (p. 184)

Ou seja, para Comênio é "essencial que a pedagogia possa ser exposta de forma pedagógica para uso de todos” (p. 184).

Pois bem, tendo isso em vista, se faz necessário que nos debrucemos sobre o que Comênio designa como “ordem natural”, "gradação natural”. Com isso será possível esclarecer

\footnotetext{
${ }^{6}$ Comênio (1966) não pretende, de fato, que o método apriorístico seja capaz de ensinar "tudo", mas que ensine o conhecimento dos fundamentos, das razões e dos objetivos das coisas principais.
} 


\section{pro.posições}

$e$-ISSN 1980-6248

http://dx.doi.org/10.1590/1980-6248-2016-0101

por que, para o autor, a estrita observância do método nas escolas é imprescindível. Cambi (1999, p. 277), por sinal, destaca que Comênio se serve amiúde da "metáfora natural” como um importante expediente discursivo em sua obra, e isso exatamente porque o método de ensino deve imitar as leis naturais, atendendo a níveis progressivos e graduais de complexidade.

É por meio da providência divina (e, logo, da natureza, que é sua extensão) que cada coisa criada se encontra infundida de determinada finalidade. Contudo, posto que implicaria uma injusta imperfeição para essas criaturas encontrar-se privadas dos meios para alcançar seus fins, a sábia providência de Deus prescreveu então a elas os “órgãos e auxílios” para atingir tais finalidades. No entanto, resta algo ainda mais relevante do que os fins e os meios naturais às criaturas: trata-se da inclinação inata - o instinto natural - com que a providência divina também destinou cada coisa a procurar pelos fins que lhe são prescritos (fins que na hipótese de deixarem de ser perseguidos pela criatura induzem ao seu sofrimento, desaparecimento e morte). Em suma: é em face da absoluta harmonia com a qual a providência natural instilou o fim, os meios e a inclinação de cada coisa que então a conservação do estado e da integridade de cada criatura de Deus é assegurada.

Mas se é verdade que o fim, os meios e a inclinação são condição suficiente para a conservação da criatura, a conservação de cada uma das criaturas, por sua vez, concorre para a manutenção da plenitude do universo:

Efectivamente, o que é que faz com que o mundo seja o mundo e se mantenha em sua plenitude? Sem dúvida, o facto de que cada criatura, segundo a prescrição da natureza, permanece escrupulosamente dentro dos seus próprios limites; esta manutenção da ordem particular conserva a ordem do universo [ênfase adicionada]. (Comênio, 1966, p. 181)

Com respeito à ordem (que não é senão a alma das coisas infundida por Deus), é, então, na medida em que cada uma das partes mantém intocada a sua ordem/alma que se conserva também a ordem do todo. Ou seja, a ordem particular das coisas concerne também, e necessariamente, à disposição de cada uma das coisas em face de todas as demais. E tanto é assim que o autor apresenta a definição de “ordem” também em termos correlacionais:

[A ordem é] a disposição das coisas anteriores e posteriores, maiores e menores, semelhantes e dissemelhantes, consoante o lugar, o tempo, o número, as dimensões e o peso devido e conveniente a cada uma delas.... Com efeito, tudo aquilo que é ordenado, durante todo o tempo 


\section{pro.posições}

$e$-ISSN 1980-6248

http://dx.doi.org/10.1590/1980-6248-2016-0101

em que conserva a ordem, conserva o seu estado e a sua integridade; se se afasta da ordem, debilita-se, vacila, cambaleia e cai. (Comênio, 1966, p 181)

Eis, assim, que a ordem para Comênio (1966) é compreendida como a "alma de todas as coisas", na medida em que cada uma delas permanece circunscrita em seus limites naturais. Mas isso ao mesmo tempo em que cada uma se dispõe em face das demais coisas, tal como the é devido e conveniente, consoante o tempo, o lugar, o número, etc. Por exemplo: o que faz com que o corpo humano, mesmo dispondo apenas de meios finitos, possa realizar um número de ações quase infinito é a "sábia proporção de todos os membros, tanto em si mesmo, como na relação de uns para com os outros [ênfase adicionada]" (p. 181).

No caso mais específico da criatura humana (ser esse que também foi infundido de um destino natural pela providência), o "erro público" cometido por todo o gênero humano através dos "primeiros pais" (Adão e Eva) acabou por corromper sua ordem natural. E, tal como ocorre a tudo o que não conserva a sua ordem/alma, a criatura humana se debilitou, cambaleou e caiu (eis que Comênio associa aí o "erro público" à chamada "queda"). E, em razão da "queda", não é condizente, portanto, que se empregue o termo "natureza" para fazer referência ao estado dos seres humanos, tal como se consolidou após tal "pecado original". A verdadeira natureza humana, para o autor, é somente aquela que um dia correspondeu à condição primitiva, integral e fundamental dos pais primeiros.

De mais a mais, é em virtude da corrupção da natureza humana que o mal, agora, nos acomete de modo fácil e tenaz. E é pela mesma razão que "a diligência e a inocência das crianças nunca nos oferecem uma confiança segura" (Comênio, 1966, p. 461). E, posto que todos nós nos encontramos distantes da luz natural com que Deus nos criou, então até mesmo os pais e os professores - adultos que deveriam socorrer as crianças e os jovens pela educação - acabam contribuindo para aumentar seu embaraço, sobretudo ao empregar nas escolas métodos confusos e obscuros.

Mas, ora, haveria alguma sorte de antídoto para esse mal que nos induziu a tamanha obscuridade? Ou, pelo contrário, estaríamos irremediavelmente condenados à privação de nossa autêntica ordem (ou alma natural) ao longo de nossa passagem pela Terra, passagem que deveria servir-nos de escola para a vida eterna? 


\section{pro.posıções}

$e$-ISSN 1980-6248

http://dx.doi.org/10.1590/1980-6248-2016-0101

A resposta de Comênio para essa pergunta crucial é conhecida: o remédio para o mal da condição humana corrompida reside em tomar como guia o "princípio natural” e em tomá-lo não de qualquer forma, mas escrupulosamente, ordenadamente (ou seja, metodicamente). É que, uma vez que a nossa ordem natural se arruinou, resta-nos olhar para os "lados", posto que já não é possível lançar um olhar para "dentro" de nós mesmos, sem que topemos com nossas decaídas inclinações adâmicas. Isto é, resta-nos apenas contemplar e, em seguida, reduplicar em nível metodológico a forma como opera a natureza.

Agindo assim - ou seja, tomando por mestre a natureza e, logo, a magna providência , poderemos remediar os males decorrentes da "queda". Eis que a mais minuciosa imitação do modus operandi da natureza ou a reduplicação de suas leis é o que permitirá então estipular o "método natural de ensino". E decorrerá, pois, de tal emprego do método pelos seres humanos a suposta certeza - tal como dizíamos anteriormente - de tudo fazer progredir gradualmente, assim como o faz a própria natureza, ou assim como o fazem, é claro, os artesãos, ao imitá-la (isto é, ao copiar-lhe o arquétipo). É que, no estado de corrupção em que se encontram o mundo dos homens e a natureza humana, nós sequer podemos progredir de grau em grau, à exceção de que utilizemos, segundo Comênio, um método tão natural quanto a lógica mesma com que se desenvolvem passo a passo todas as coisas que são naturais.

Eis que progredir gradualmente implica, portanto, nunca passar às coisas que vêm à frente, sem que antes disso se tenham "consolidado com o necessário cuidado as coisas que estão primeiro" (Comênio, 1966, p. 237). Em outras palavras, o progresso gradual implica a transformação de cada coisa, sem que nessa transformação se ponha em risco a harmonia da criatura em face de seu fim, de seu meio e de sua inclinação. O progresso gradual implica, ademais, a transformação da disposição das coisas entre si, sem, com isso, comprometer a harmonia geral de cada uma delas com todas as outras.

Em síntese, a gradação pode ser concebida como o movimento devidamente disposto de uma máquina. E tal máquina - constituída de partes que se mantêm escrupulosamente dentro de seus limites e que se dispõem ordenadamente entre si - conserva então sua alma, não obstante seu movimento, sua transformação. Desdobrando-se um pouco mais a analogia, poderíamos dizer que a "ordem" está para a "máquina", assim como a "gradação" está para a "transformação" que essa máquina convenientemente ordenada nas partes e no todo realiza. A gradação é, pois, a ordem em transformação e sem desordem. 


\section{pro.posıções}

http://dx.doi.org/10.1590/1980-6248-2016-0101

$e$-ISSN 1980-6248

Transportando tal concepção gradualista para o campo epistemológico, podemos afirmar que a aquisição do saber pelos seres humanos começa a partir dos sentidos. Depois, migra para a memória por meio da imaginação (isto é, a partir de imagens das coisas sensíveis). E nessa progressão o saber - por força da indução realizada a partir das coisas singulares atinge então a inteligência do conceito universal, culminando dessa forma na emissão do juízo sobre as coisas estudadas (vale lembrar que, para Comênio, é pelo juízo que se atinge a verdadeira ciência).

E a boa organização da instituição escolar deve se pautar, por sua vez, pela mesma progressão epistemológica que vai do sensível aos juízos da ciência. Isto é, é necessário que a cada ano o programa de cada classe seja metodicamente desenvolvido, e de tal modo, que todos os alunos sejam conjuntamente promovidos - de acordo com a mencionada gradação dos conhecimentos - para uma classe superior. É preciso mesmo que a totalidade dos estudos escolares seja dividida, tendo em mente tais classes e distribuindo meticulosamente o tempo em cada uma delas. E isso de tal maneira que a cada ano, mês, dia e hora corresponda uma tarefa especial. E se a cada hora o aluno "aprender um só teorema de qualquer ciência, ou uma regra de uma arte prática, ou uma história interessante ..., que tesoiro de instrução se conseguirá adquirir?!” (Comênio, 1966, p. 202). Por certo, nós então nos deparamos aqui com aquilo que Narodowski (2001) nomeia de "simultaneidade sistêmica" (p. 83): na Didática Magna tal simultaneidade sistêmica conjuga, segundo o autor argentino, a universalização da oferta de conhecimentos escolares à homogeneização do funcionamento da instituição escolar. E, tal como se pode depreender do que foi asseverado antes, tal sistematicidade presente na Didática Magna não "pararia de pé” sem a ideia de progressão gradual.

Em decorrência dessa progressão do programa escolar tanto em seu todo como em cada uma das partes, o "tesouro da instrução" - isto é, o estudo de uma vida inteira - se estruturará então como uma "enciclopédia pansófica". Hilsdorf (2006), a propósito disso, assevera que Comênio foi mesmo o "propositor da via enciclopédica da investigação científica do século XVII” (p. 82). Trata-se, no caso de tal via, de uma investigação em que os conhecimentos já estabelecidos progridem gradativamente, ao passo em que se dão as novas descobertas (eis aí a ordem em transformação e sem desordem). No interior de tal enciclopédia, por certo, nada pode haver que não tenha brotado de uma raiz comum ou que não esteja assente em seu justo e devido lugar (inclusive as novas descobertas, é claro). E essa ordem e sua gradação, por sua 


\section{pro.posıções}

http://dx.doi.org/10.1590/1980-6248-2016-0101

\section{$e$-ISSN 1980-6248}

vez, oferecem a garantia de que, na escola universal, o aluno poderá adquirir o referido tesouro enciclopédico da instrução. Graças a essa gradação - na qual o devir natural é tomado como mestre - os alunos podem então ser conduzidos, supostamente, a qualquer altura do saber. Ou, tal como afirma Narodowski (2001): para Comênio a infância progride de grau em grau. Isto é, ela se situa, em sentido cartesiano, na "ordem das razões" (p. 48). E, assim como ocorre a tudo aquilo que é ordenado segundo as regras da razão, a infância não pode ser senão um ponto de partida simples, sobre o qual se erige gradualmente uma cadeia que, dividida em tantas partes quanto necessário, permite atingir, ao cabo dela, um ponto pleno (a idade adulta). Nesse sentido, a diferença entre a idade infantil e a adulta é apenas de grau. E, uma vez mais, é essa gradação ordenada que permite que, na escola, a infância seja metodicamente conduzida até os pontos mais altos do conhecimento.

Ora, sob tal perspectiva, o professor começa a despontar, pois, como uma engrenagem numa máquina que, convenientemente organizada e harmonizada em suas partes e em seu todo, poderá ser posta em movimento, sem o risco de deixar de progredir seguramente. E isso será garantido somente se o professor seguir o modus operandi da natureza e, portanto, o da magna providência - expediente imprescindível para recompor a ordem perdida desde a "queda" do ser humano.

Todavia, em vista dessa pretensão de replicar nos mais diversos níveis da escola a gradação natural, não é de espantar que comentadores do autor concluam - e queremos manifestar nossa discordância parcial em relação a essa conclusão - que o pensamento de Comênio só poderia conduzir a uma concepção tipicamente "ortopédica" de educação. No mais, seria ainda em vista de tal "ortopedia" que se deveria então levar a cabo, ano após ano, a manutenção estrita de uma mesma ordem geral da escola, e em função do que restaria ao professor realizar, tal como um astro, sempre o mesmo e exato curso em torno da multidão de alunos. Isto é, para o morávio seria o caso, supostamente, de se implantar um tão estrito controle metodológico sobre a escola, sobre os programas, o currículo, o aluno e, principalmente, sobre o professor, que, por consequência, este último despontaria apenas como um executor de um plano prévia e absolutamente resolvido pela metodologia de ensino.

De mais a mais, o professor seria, vale acrescentar, não apenas o executor do método totalmente estabelecido a priori, mas também o replicador dos conhecimentos engendrados e autorizados pelos acadêmicos ou eruditos da "sociedade dos homens doutos" (Comênio, 1966, 


\section{pro.posıções}

$e$-ISSN 1980-6248

http://dx.doi.org/10.1590/1980-6248-2016-0101

p. 471). Tais estudiosos são, para Comênio, os dignos condutores dos outros homens e são também aqueles trabalham em nome da descoberta dos fundamentos da ciência e da difusão dessa sabedoria para todo o gênero humano. Tal difusão, por certo, ocorreria nas escolas universais por meio de professores universais. Ora, de acordo com essa visada, o professor comeniano - verdadeira "peça" sem vida no maquinário escolar - se encontraria, portanto, totalmente subsumido ao método e também à veiculação mecânica de "enunciados epistêmicos" preparados pela "sociedade dos homens doutos", o que definitivamente implicaria que a enunciação desse professor (isto é, seu ato singular de fala) fosse desprovida de qualquer valor.

Ao professor comeniano restaria, por suposto, apenas a missão de proceder como um operário ou como um "tipógrafo escolar" - segundo metáfora do próprio autor ${ }^{7}$. Ou seja: assim como é graças à tipografia que "até mesmo aqueles que não sabem escrever elegantemente" (Comênio, 1966, p. 456) podem vir a imprimir livros com elegância, seria então em razão da ordenação natural e gradual do método de ensino que qualquer pessoa poderia se tornar professor, e isso independentemente de seus traços psíquicos singulares, de sua implicação subjetiva com o ensino, de suas representações mentais conscientes e inconscientes, de seu discurso sobre a escola e seus propósitos, etc.

Em uma palavra: o mestre não passaria aí de uma espécie de "encarregado" de um trabalho pré-decidido pelas inteligências mais engenhosas, uma vez que aquele, como “tipógrafo-escolar", já não teria agora de "escrever" com as próprias mãos, mas sim "por meio de caracteres propositadamente preparados para isso" (Comênio, 1966, p. 456). Desse modo, entre o professor e o tipógrafo já não haveria, pretensamente, qualquer diferença significativa. Um professor na escola seria uma figura tão "anônima" quanto um operário numa linha de produção.

Ora, a nosso ver, talvez nem tudo seja tão categórico em se tratando do autor em tela. Como de praxe, não se pode esquecer que, no caso de Comênio, é preciso, sempre, levar em conta certas antinomias. É, pois, o "lado b" da Didática Magna, no que toca ao professor, que tentaremos trazer à baila na sequência - ainda que somente o possamos fazer, é claro, de modo parcial.

\footnotetext{
${ }^{7} \mathrm{O}$ artesão, ao criar artefatos, copia, segundo Comênio, o arquétipo da natureza (ordem, gradação, etc.). Daí que as ações do professor - tão radicalmente pautadas pelo método natural - possam ser comparadas às do artesão e talvez até às do operário.
} 


\section{pro.posıções}

http://dx.doi.org/10.1590/1980-6248-2016-0101

\section{$e$-ISSN 1980-6248}

\section{A vez e a voz do professor na Didática Magna}

Também a nós nos parece que, em face da divisão do trabalho que já era possível testemunhar no século $\mathrm{XVII}^{8}$, o autor morávio se deu conta de que as máquinas estavam "dispensando as características individuais" dos trabalhadores (Gasparin, 1994, p. 86), assim como o "maquinário" do método de ensino e os enunciados de conhecimentos estabelecidos poderiam dispensar, na escola, a singular enunciação dos professores. Em razão de estarem os recursos e bens materiais cada vez mais difundidos socialmente, Comênio se deu conta de que já não era preciso, no século XVII, executar certos trabalhos com as próprias mãos, mas antes "por meio de produtos humanos, [como por exemplo] os caracteres tipográficos, que já não requerem gênios para reproduzir com perfeição uma obra" (Gasparin, 1994, p. 86). Ora, por suposto, o acesso público a métodos e conhecimentos universais, assim como a artefatos e outros bens materiais, dispensaria a implicação subjetiva por parte das pessoas em geral com aquilo que executam e, no que tange especificamente à escola, dispensaria a implicação subjetiva do professor com aquilo que ensina bem e também o envolvimento do aluno com aquilo que aprende. Por sinal, podemos ouvir na voz. do próprio Comênio (1966) essa opinião, no que concerne à profissão docente:

Serão hábeis para ensinar [graças ao reto ordenamento do método], mesmo aqueles a quem a natureza não dotou de muita habilidade para ensinar, pois a missão de cada um não é tanto tirar da própria mente o que deve ensinar, como sobretudo comunicar e infundir na juventude uma erudição já preparada e com instrumentos já preparados, colocados nas suas mãos. Com efeito, assim como qualquer organista executa qualquer sinfonia, olhando para a partitura, a qual talvez ele não fosse capaz de compor, nem de executar de cor só com a voz ou com o órgão, assim também porque é que não há-de o professor ensinar na escola todas as coisas, se tudo aquilo que deverá ensinar e, bem assim, os modos como há-de ensinar, o tem escrito como que em partituras? [ênfase adicionada]. (p. 457)

Eis que a máquina e o método, tanto quanto os “enunciados” prontos e universalizáveis, acabariam por igualar "todos os homens no processo de produção tanto material quanto intelectual " (Gasparin, 1994, p. 87). E, em particular, o método de ensino assumiria com isso “completamente a condução do processo da ação docente" (p. 87). Em outros termos, o método

\footnotetext{
${ }^{8}$ Tal como assinalam as seguintes passagens, dentre outras, da Didática Magna (Comênio, 1966): “os pais, ocupados com negócios domésticos, não podem observar tão estritamente a ordem nas escolas públicas, onde não se faz outra coisa senão educar a juventude" (p. 421); e "vemos que cada ciência se alarga tão amplamente que pode preencher toda uma vida" (p. 141).
} 


\section{pro.posıções}

$e$-ISSN 1980-6248

http://dx.doi.org/10.1590/1980-6248-2016-0101

comeniano implicaria, segundo Gasparin, a "universalidade da uniformidade" (p. 91) e de tal sorte que "os homens, utilizando os mesmos instrumentos de trabalho" e se valendo do mesmo saber público ou universal, tornariam então "iguais suas produções, independentemente das características pessoais de cada um" [ênfase adicionada] (p. 91). Na esteira disso, o método de Comênio passaria, supostamente, a uniformizar ou homogeneizar os professores na mesmíssima proporção com que uniformizaria ou homogeneizaria os alunos.

Ora, com respeito a essa "uniformidade da universalidade" ou a essa "universalidade da uniformidade", podemos afirmar que também ela se encontra mergulhada em antinomias relevantes no caso de Comênio. E, a nosso ver, a concepção de Manacorda (1992), segundo a qual a escola comeniana seria como uma tipografia viva, atesta isso muito bem. É que, muito embora Comênio (1966) proponha, afinal, que a missão de cada professor não seja tanto a de "tirar da própria mente o que deve ensinar", mas, sobretudo, "comunicar e infundir na juventude uma erudição já preparada [enunciados epistêmicos] e com instrumentos [sobretudo a metodologia] já preparados, colocados nas suas mãos [pelos sábios ou eruditos da academia]" (p. 457), nosso autor, por outro lado, afirma também que o professor é como um organista que executa uma sinfonia a partir de uma partitura.

Ora, um organista que executa uma sinfonia pode eventualmente não ser, é claro, o autor da sinfonia; todavia, a execução nem por isso deixa de receber as marcas do estilo, da interpretação, da singularidade ou dos "rasgos" do músico que a interpreta. Em princípio, poderíamos afirmar que tal organista é "coautor" da sinfonia que executa, no sentido ao menos de que é ele quem empresta "vida" à "letra morta" e silenciosa que habita a superfície da partitura. Sendo assim, tal metáfora se presta a relativizar, em alguma medida, a afirmação de que o professor deveria se limitar a difundir publicamente aos jovens uma erudição já totalmente pré-decidida através de um método já totalmente preparado.

Para Comênio talvez esteja em pauta, a um só tempo, a metódica difusão de conhecimentos públicos (isto é, de "conhecimentos socialmente validados”), mas também algo que diz respeito à enunciação daquele que professa tais conhecimentos diante de seus alunos. Por sinal, Comênio (1966) chega a propor que o professor deve, de fato, "adoçar o método" (p. 457) ou que o mestre deve - mesmo que isso não signifique transformar o método tido como natural - introduzir ligeiras variações e diversificações metodológicas que se pautarão pela “peculiar relação das línguas [ensinadas na escola] ou das artes entre si, e na capacidade e no 


\section{pro.posıções}

$e$-ISSN 1980-6248

progresso dos alunos” (p. 457). Em uma palavra: não obstante o método deva ser deduzido a priori, resta algum espaço para que o professor o "adoce", a depender das circunstâncias.

Entretanto, talvez haja algo ainda mais significante do que isso na Didática, e que se relaciona com o modo como Comênio (1966) situa o professor na metáfora da "tipografia viva", isto é, na "metáfora didacográfica" da qual o autor se serve para representar tão vivamente a escola:

Na Didacografia ....O papel são os alunos, em cujos espíritos devem ser impressos os caracteres das ciências. Os tipos são os livros didácticos e todos os outros instrumentos propositadamente preparados para que, com a sua ajuda, as coisas a aprender se imprimam nas mentes com pouca fadiga. A tinta é a viva voz do professor que transfere o significado das coisas, dos livros para as mentes dos alunos. O prelo é a disciplina escolar que a todos dispõe e impele para se embeberem dos ensinamentos [ênfase adicionada] (p. 458).

Como Comênio o afirma, a tinta é a viva voz do professor, e faz da escola uma autêntica tipografia viva (Manacorda, 1992). E, por mais que esteja em jogo aí a transferência do significado das coisas, a partir dos livros, para a mente dos alunos (o que em princípio faria do ensino e do aprendizado "réplicas" ou "cópias" um do outro), o fato é que, sem a voz do professor, não seria possível conferir vida aos "tipos móveis" dos livros didáticos, ou seja, à "erudição já preparada" pela academia dos doutos. E é exatamente essa vida conferida pelo professor àquilo que ele ensina em suas aulas que propicia ao aluno aprender um conhecimento igualmente vivo, e não uma mera "réplica" ou "cópia" daquilo que lhe é ensinado. Eis que a emergência da voz do professor é, portanto, nada menos do que propriamente vital na Didacografia, dado que sem ela o conhecimento público, no que concerne ao ensino escolar das novas gerações, acabaria se tornando letra morta sobre a superfície de papel dos livros didáticos - ou até mesmo na cabeça do aluno, conquanto o aprendido por este fosse absolutamente idêntico ao ensinado pelo professor, ou seja, conquanto o desejo do aluno de conhecer não tivesse lugar algum na Didacografia ${ }^{10}$. Ora, isso talvez queira dizer, afinal, que nem o ensino nem tampouco a educação

\footnotetext{
${ }^{9}$ Comênio nomeia o método de ensinar tudo a todos também como "Didacografia", uma vez que, graças a tal método, poder-se-ia fazer imprimir na mente dos alunos - ao mesmo tempo e por meio do ensino de um só professor - o conhecimento de todas as coisas, ou melhor, o conhecimento dos fundamentos, das razões e dos objetivos das coisas principais.

${ }^{10}$ Comênio (1966), por sinal, afirma que o desejo de conhecer é "atiçado" na escola, conquanto o professor enseje ao aluno que se reconheça ignorante em determinado assunto. E é, pois, em face de tal reconhecimento que o aluno se lança então à aquisição do conhecimento. Trata-se de escavar o poço do desejo de saber no aluno, de tal forma que a água passe então a minar também do interior do poço e não apenas de fora dele.
} 


\section{pro.posições}

$e$-ISSN 1980-6248

http://dx.doi.org/10.1590/1980-6248-2016-0101

são redutíveis a operações automáticas (como certas artes mecânicas, de fato, o são). É que, no caso da educação - ao menos segundo o ponto de vista psicanalítico -, não há "garantias externas" ao processo, uma vez que, sem a implicação subjetiva do professor com seu ensino, bem como a do aluno com seu aprendizado, nada de vivo chega a se consumar na formação escolar ${ }^{11}$.

Sendo assim, por mais que a máquina e o método impliquem, em alguma medida, igualar "todos os homens no processo de produção tanto material ou intelectual" (Gasparin, 1994, p. 87), e isso de tal forma que o produto final seja o mesmo, independente de quem o produziu, a particularidade da voz do professor (sua enunciação) opera como um contraponto a toda uniformização universalizante ou a toda universalização uniformizante na escola. Afinal, e tal como se costuma pensar no campo da Psicanálise e Educação, é graças a sua viva voz que o professor confere singularmente um dom aos conhecimentos públicos que ensina; é por meio dela que ele anima, como se fosse um operador de marionetes, os conteúdos acadêmicos; é com sua fala que o professor chama à vida novamente as tradições epistêmico-escolares que já existiam desde muito antes de os alunos chegarem ao mundo (Arendt, 2000). Enfim, sem tal tinta o maquinário "tipográfico" ou escolar não é capaz de ensinar nada a ninguém, ao menos no sentido humano e subjetivante do termo. Já, ao contrário disso, e tal como foi afirmado aqui, a pretensão da racionalidade técnico-instrumental no campo da educação é massiva, justamente em função do seu objetivo de fazer do ensino e do aprendizado pares narcísicos, ou seja, "clones". Afinal, tal pretensa univocidade entre o ensinado e o aprendido é o que daria prova clara e distinta do controle técnico exercido na educação a partir da estrita observância metodológica.

Muito embora Comênio não tenha dúvida de que, em nome dos conhecimentos enciclopédicos a serem universal e metodicamente difundidos, o "astro rei" (o professor) de fato deva repetir a cada ano o mesmíssimo curso em torno de seus alunos, nem por isso esse mestre surge aí, apenas, como um replicador de conhecimentos enciclopédicos, como o operário-executor de um método prévia e absolutamente resolvido, ou simplesmente como o tipógrafo-mestre da instrução escolar. Isto é, embora para Comênio as escolas universais

\footnotetext{
${ }^{11}$ É nesse sentido que se afirma, na Psicanálise e Educação, que a educação constitui um ofício “impossível”. Isto é, não há nada que possa assegurá-lo a priori, muito embora o engajamento subjetivo por parte de alunos e professores na educação escolar costume, sim, produzir efeitos formativos, educativos.
} 


\section{pro.posıções}

http://dx.doi.org/10.1590/1980-6248-2016-0101

$e$-ISSN 1980-6248

requeiram, de fato, professores universais, eles não se restringem a meros professores sem "tinta", a mestres "mudos". Antinomicamente, é, de fato, a viva voz do professor o “instrumento" pelo qual a execução de uma "sinfonia universal" pode virtualmente se fazer ouvir por todos os alunos de um sistema escolar, e assim tal sinfonia talvez se torne apreciável para cada um desses mesmos alunos. Ou seja: uma vez que os "corpos de enunciados teóricos" (de Química, Biologia, História, etc.) não são, eles mesmos, capazes de "saltar" da superfície de papel dos livros em que habitam, a fim de se fazer imprimir textualmente na cabeça dos alunos, é necessário então que na escola - tal como se tem debatido na Psicanálise e Educação - seja colocada em cena necessariamente uma voz, uma enunciação, uma fala singular que verse acerca de tais conhecimentos públicos. E, ao se dar lugar, desse modo, ao professor e a seu ensino, os puros enunciados epistêmicos e até mesmo o método já não restarão exatamente os mesmos, uma vez que poderão receber, mediante isso, vida; vida a qual relança a sorte da transmissão de conhecimentos, ao passo que invoca a enunciação singular do aluno, sua viva subjetividade, sua vOz, seu desejo de conhecer. Eis que é a enunciação do professor que suscita, na escola, a enunciação do aluno. E eis que são essas enunciações, segundo a Psicanálise e Educação, que afastam o risco de que a universalização dos enunciados epistêmicos produza a estrita uniformização ou homogeneização dos sujeitos no interior das instituições escolares.

\section{A título de conclusão}

Segundo a Didática Magna (Comênio, 1966), é imprescindível que venham a ser abertas escolas para formar os jovens, uma vez que os pais “ocupados com os negócios domésticos não podem observar a [mesma] ordem [que se observa] nas escolas públicas, onde não se faz outra coisa senão educar a juventude" (p. 421). E os jovens de todas as idades, de ambos os sexos, de todas as extrações sociais - incluindo os "operários, agricultores e moços de frete" (p. 143) - e até mesmo os débeis devem, por igual, ser enviados a essas escolas universais. Eis aí, aliás, a ardorosa convicção de Comênio em torno da universalização da educação. Tal como observa Gomes (1966), Comênio foi mesmo o "mais ardente apóstolo da universalização do ensino" (p. 35), sendo que a referida universalização não poderia se realizar na ausência de um projeto escolar amplamente renovado. Para Narodowski (2001), Comênio quis consumar através da 


\section{pro.posições}

$e$-ISSN 1980-6248

http://dx.doi.org/10.1590/1980-6248-2016-0101

escola a distribuição universal dos saberes gerados pela humanidade. Ora, ensinar "tudo" a todos não seria possível, nos termos de Comênio, senão graças à "progressão gradual".

Ou seja, desde que as escolas busquem a exata ordem em todas as coisas, poderão corresponder efetivamente à sua finalidade, que não é senão a de ensinar universalmente - e, "de quebra", restituir a ordem originalmente infundida por Deus na alma humana. Para que nelas se possa ensinar e aprender com segurança - a saber, "de modo que seja impossível não obter bons resultados" (Comênio, 1966, p. 205) -, é imprescindível que a arte de ensinar leve a cabo a mimese metódica da natureza. Ou, como Comênio (1966) ressalta, citando Cícero: "Se seguirmos a natureza por guia, nunca erraremos" (p. 190). Afinal, a natureza é a filha de Deus.

Ora, é pertinente perguntar qual é o lugar do professor em uma instituição escolar na qual o progresso gradual é entendido como a harmoniosa transformação - tanto no plano particular quanto no universal - dos elementos constitutivos dessa instituição, e em função do que a "máquina escolar" poderia ser posta em funcionamento, sem que se corrompesse sua ordem. O professor seria aí apenas uma peça governada pelo método natural, uma vez que tal método daria a garantia de tudo fazer progredir de grau em grau, sobretudo o aprendizado do aluno? E, se a ordem do método reduplica a da natureza, e essa reduplica, por sua vez, a ordem divina, caberia então ao professor algo mais do que executar o script fechado que lhe prescreve manter-se metodicamente dentro de seus próprios limites no interior da instituição escolar? Em suma: a escola universal de Comênio estaria submetida à mais estrita ortopedia educacional, à mais massiva uniformização dos saberes, à mais categórica homogeneização tecnicista dos alunos, em meio às engrenagens do "maquinário tipográfico"?

Bem, a resposta talvez fosse "sim", não fosse o fato de que, até mesmo para os fins da doutrinação religiosa, a "voz" cumpre uma função em nada "anônima”. É que na Didática Magna o Espírito Santo é tomado como o Reitor ou Mestre supremo da escola celestial, enquanto os apóstolos são os professores, e os eleitos de Deus são os alunos (Comênio, 1966). Ou ainda: Deus é nomeado como "Professor" ou "Mestre", enquanto a voz dos profetas é a doutrina, e já os humanos somos os alunos (p. 374). Invertendo a analogia, podemos asseverar que, na escola terrena, os acadêmicos da "sociedade dos homens doutos" estão para o Espírito Santo, assim como os professores escolares estão para os apóstolos. Decerto, são os acadêmicos que preparam os conteúdos eruditos que serão metodicamente ensinados pelos professores nas escolas aos alunos. Ora, haverá nisso algo que autorize dispensar a enunciação dos professores 


\section{pro.posições}

http://dx.doi.org/10.1590/1980-6248-2016-0101

$e$-ISSN 1980-6248

nas escolas universais? Entendemos que não. Muito pelo contrário, o fato é que a voz dos professores nas escolas terrenas possui dignidade análoga à da vOz dos profetas na escola celestial. E convenhamos que a voz desses não pode ser pouco importante para um teólogo protestante como Comênio. Ora, como se vê aí, a questão é que a letra do corpo doutrinal religioso se confunde com a voz mesma dos profetas. Em suma, é a voz que confere vida à letra também nesse caso. Ou, em outras palavras: até mesmo no âmbito estritamente religioso Comênio evita posicionar o profeta de modo a submetê-lo a uma veiculação puramente repetitiva de enunciados religiosos. Eis que a voz dos profetas é a tinta da religião. E, sem tal tinta, os eleitos de Deus (os alunos) poderiam acabar ficando privados de aprender aquilo que o Reitor ou Mestre Supremo determinou que fosse ensinado na escola celestial, a fim de ficar impresso na alma dos eleitos.

Ainda de modo análogo a isso, Comênio (1966) afirma que os livros na escola são mestres mudos, enquanto os professores são, como tanto se reitera aqui, mestres loquazes. Isto é, a letra muda dos livros didáticos carece de quem, estando vivo não apenas biologicamente, assuma a responsabilidade simbólica de fecundar tal letra, para, assim, transmiti-la aos mais novos. Trata-se, pois, de rejuvenescê-la, de lhe emprestar voz para, dessa forma, restituir sua significância. E, para tanto, os conhecimentos, bem como o método natural preparados pelos doutos, não são suficientes (embora não sejam dispensáveis). Afinal, não basta reproduzi-los mecanicamente para os alunos. Tal como tem sido objeto de reflexão na Psicanálise e Educação, é necessário, para que uma educação se torne possível, que o professor se engaje subjetivamente com os conteúdos e até mesmo com a metodologia de que se serve ao ensinar (colocando, dessa forma, "algo de si" neles). Na ausência disso, a veiculação de conhecimentos públicos na escola fica marcada pelo "anonimato" de quem os ensina. E é razoável admitir que um ensino anônimo suscita um aprendizado anônimo ou, até mesmo, o não aprendizado.

Mas desçamos do Céu à Terra: a boa e imprescindível ordem técnica pode até ter igualado virtualmente os homens, desde a modernidade, no que diz respeito aos processos de produção. E, posto que com isso o produto final deixou de depender tanto de quem o produz, qualquer um poderia, desde então, se tornar "professor", ao menos no sentido de um executor mecânico de um método meticulosamente organizado, e em função do qual o encontro escolar com os alunos passaria a ter local, dia, mês, hora, assunto, etc., prévia e cabalmente resolvidos. Por sinal, as escolas contemporâneas que aderem aos sistemas de ensino apostilados costumam 


\section{pro.posições \\ $e$-ISSN 1980-6248}

http://dx.doi.org/10.1590/1980-6248-2016-0101

ser tristes exemplos disso. Em um desses renomados sistemas, até mesmo a piada a ser contada pelo professor na aula é predefinida e está datada no programa. Eis aí, então, a consumação estrita da suposta superfluidade do professor, em vista da observação objetiva das prescrições de um método anônimo de ensino.

Todavia, resta saber se, na hora $\mathrm{H}$, o deflagrar de um processo “educacional” puramente automático daria conta realmente da formação de pessoas que, devendo habitar com seus pares em um mundo em comum, são ímpares, irrepetíveis, insubstituíveis; ou se, ao contrário, é exigido algo mais do professor na formação escolar dos alunos, como, por exemplo, o testemunho tácito ou inconsciente de sua irrepetibilidade subjetiva, ao ensinar conhecimentos publicamente compartilhados. Segundo a Psicanálise e Educação, é, pois, esse vivo testemunho por parte de quem ensina que suscita em quem aprende o desejo de se apropriar dos conhecimentos socialmente validados transmitidos na escola. Daí a relevância atribuída neste artigo ao modo autoral (e não tecnicamente massificado) de um professor se relacionar com o saber. Afinal, é por meio de tal relação que um mestre pode chamar de novo à existência, diante de seus alunos, a erudição já preparada.

A nosso ver, a "tipografia universal" de Comênio é uma tipografia viva (Manacorda, 1992), na medida em que se safa dos riscos de massificação ou homogeneização, e isso em função de que Comênio, de modo antinômico, preserva um lugar relevante (ou no mínimo preserva uma "brecha" razoável) para a voz do professor, isto é, para seu ato singular de fala (enunciação), ou para - no limite - seu "estilo" de veicular a erudição. Nesse sentido, o que talvez o campo da Psicanálise e Educação possa oferecer como contribuição à leitura da Didática Magna seria o seguinte: ao passo que Comênio não exclui totalmente a enunciação do mestre (e, logo, a do aluno) na educação escolar, Comênio encontra, então, um bom contrapeso para a racionalidade técnica que ele mesmo faz operar hegemonicamente em sua tipografia universal. Ou seja: sua tipografia se mantém viva justamente em função dessa não exclusão do sujeito (e a qual depende vitalmente da antinomia que pretendemos ter trazido à baila aqui). A propósito, vale lembrar ainda que, na Psicanálise, a enunciação é "a propriedade mais específica do que é um sujeito", tal como afirma Lebrun (2004, p. 66).

Em Comênio, a enunciação do professor tem valor e, em decorrência disso, a do aluno também. E, sem elas, a veiculação escolar de conhecimentos públicos (o ensino e o aprendizado) não poderia ser mais do que uma operação automática e, portanto, desumanizante (posto que dessubjetivada). Restaria ver, por fim, se no discurso educacional contemporâneo reservamos ou não um lugar para a voz do professor em meio ao sistema de ensino e ao dispositivo escolar. 


\section{pro-posıções}

$e$-ISSN 1980-6248

http://dx.doi.org/10.1590/1980-6248-2016-0101

\section{Referências}

Arendt, H. (2000). Entre o passado e o futuro. São Paulo: Perspectiva.

Cambi, F. (1999). História da pedagogia. São Paulo: Unesp.

Cauly, O. (1999). Comenius: o pai da pedagogia moderna. Lisboa: Instituto Piaget.

Comênio, J. A. (1966). Didáctica Magna: Tratado da arte universal de ensinar tudo a todos. Lisboa: Calouste Gulbenkian.

Gasparin, J. L. (1994). Comênio ou da arte de ensinar tudo a todos. São Paulo: Papirus.

Gomes, J. F. (1966). Introdução. In Comênio, Didáctica magna: tratado da arte universal de ensinar tudo a todos. Lisboa: Calouste Gulbenkian.

Hilsdorf, M. L. S. (2006). O aparecimento da escola moderna: uma história ilustrada. Belo Horizonte: Autêntica.

Lebrun, J. P. (2004). Um mundo sem limite: ensaio para uma clínica psicanalítica do social. Rio de Janeiro: Companhia de Freud.

Manacorda, M. (1992). História da Educação: da Antiguidade aos nossos dias. São Paulo: Cortez.

Narodowski, M. (2001). Infância e poder: conformação da pedagogia moderna. Bragança Paulista: Editora Universidade São Francisco.

Submetido à avaliação em 22 de julbo de 2016; revisado em 1 de dezembro de 2016; aceito para publicação em 21 de dezembro de 2016. 